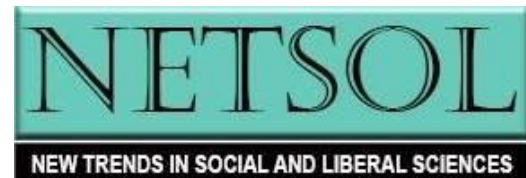

An Interdisciplinary Journal

http://www.netsoljournal.net/

Volume 6, Issue 1, pp.34-46, Spring 2021

https://doi.org/10.24819/netsol2021.03

Date Submitted: January 20, 2021

Date Accepted: May 24, 2021

\title{
Impact of the Covid-19 Pandemic on Anxiety Levels of Medical Students in Pakistan
}

\author{
M. Ahmad Mukhtar, Nishtar Medical University (NMU), Pakistan \\ Mukhtar Hussain, Quaid E Azam Medical College (QAMC), Pakistan \\ M. Omer Mukhtar, Beaconhouse School System (BHS), Pakistan \\ Muhammad Sajid, MINAR Cancer Hospital, Pakistan
}

\begin{abstract}
Covid-19 is a communicable infective disease and has been the major current health challenge since it emerged in China in late 2019. Although earlier data analyses of Dawei Wang etc. from 138 hospital of China had shown that its mortality rate is less than 5\%, shown (4.3\%), major concern is its widespread transmission. The Covid-19 pandemic has adversely affected economics and the mental health of millions worldwide. Fear is the one of the psychological outcomes of pandemic, but the psychological impact of the pandemic was overshadowed by financial and economic impact, which are interrelated. Conducted through an online questionnaire, this study evaluates the anxiety level of medical students of Nishtar Medical University and Multan and Quaide-Azam Medical College (QAMC) Bahawalpur in southern Punjab of Pakistan by using fear Covid19 scale. The research employs the fear scale developed by Ahorsu et al. based on unidimensional 7 items, 5-point Likert scale. This scale is a valid and reliable tool and has been used to assess the fear for Covid-19 in general population. This scale has been used internationally by many researchers to measure anxiety levels.

The research correlated the socio demographic variables, such as age, sex, education level and living surroundings, with anxiety levels that would help to redesign curriculum for education and to plan programs to enhance the knowledge of medical students for preventive measures against Covid-19. 577 male and female students from $1^{\text {st }}$ to $5^{\text {th }}$ year of bachelor's in medicine and bachelor's in surgery (MBBS) with ages ranging from 17 to 25 years participated in this study.
\end{abstract}

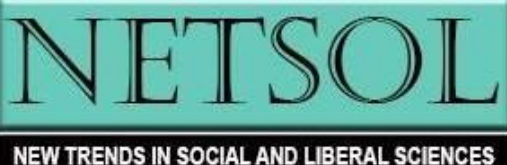


Conclusion: Our study shows that the Covid-19 has created fear and phobia that is affecting the mental health of medical students. Health programs is a basic requirement at the time to minimize the psychological impact of phobia in medical students.

Key Words: Covid-19, Pandemic, Anxiety, Fear Scale, Medical students, Pneumonia

\section{Introduction}

The Corona virus disease 2019 (Covid-19) outbreak began in Wuhan, China in December 2019 with manifestations of respiratory symptoms associated with fever and fatigue progressing to pneumonia and even death in some cases. The World Health Organization (WHO) has declared it pandemic with infecting millions of people and more than one million losses of lives worldwide. Health care system all over the world have been utilizing most of their resources with primary focus on treatment of infected patients and prevention of its further spread with little attention towards its psychological impact resulting from fear and phobia as is already proven by literature on the toll on mental health caused by different pandemics in the past (Huremović 2019; Chong M-Y et. al., 2004).

Fear is a natural bodily response to stress with a feeling of apprehension about the outcome. Occasional fear is a normal phenomenon, for example going for an interview or giving a speech may cause many people experience nervous and mild anxiety. If this feeling of anxiety interferes with daily activities, it may lead to different anxiety disorders. Fear could be generated in a planned manner in the health sector by messages perceived as threatening, it's called 'fear appeal' (Pakpour, 2020). Fear appeal is used to change the behavior of public towards some factors or habits, those that are injurious to health. Fear appeal has successfully worked on topics of cigarette smoking, breast cancer screening by self-breast examination, and medication adherence (Tannenbaum, 2015). The protection motivation theory defined by R. W. Rogers explains that the individual adopt health behaviors only when their expected susceptibility and severity is high. (Pakpour, 2020). Similar fear appeal has been utilized as a motivational factor against the prevention of Covid-19 by public messages to change the behavior for social distancing, frequent hand washing, use of hand sanitizer, and use of face masks. A recent study has shown that people adopt more preventive measures when they perceive high threat (Harper et.al, 2020).

Media has an unquestionable role in spreading these health related fear appeals but on the other hand the news and regular updates on the number of Covid-19 related deaths and infected people generates anxiety in the public (Sher, 2019). Such anxiety disorder has resulted in increased rate of suicides triggered by behavioral and psychological consequences of lockdown, isolation, feeling of loneliness, fear, and anxiety (Sher, 2020).

Many studies have been conducted to measure fear against medical conditions including fear for breast cancer, dementia, surgery, hypoglycemia, and Alzheimer's disease. Champion and his colleagues developed the Breast Cancer Fear Scale that was used by M. Moshki and his colleagues to evaluate fear and anxiety in the Iranian population (Monshki et.al., 2017). Samantha L. French utilized and validated the scale for fear of Alzheimer's disease (FAD) to measure the anxiety level in the general population (French, et. al., 2012). Different scales have been designed

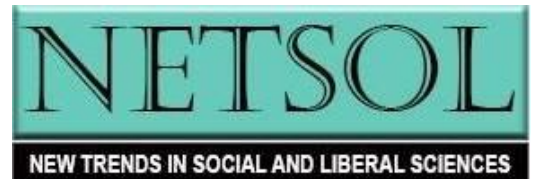


to measure the anxiety level in different social groups against specific topics. Measuring the anxiety level for a specific factor in different groups using specific social and demographic variables including age, gender and education helps to plan for education and prevention programs.

Medical school students are assets of the health care system. They are the first line of soldiers on the battle against pandemics. Their self-care abilities need to be strengthened to deal with a pandemic. The mental health of medical students has already been seen to be a worldwide problem (Kaper, et.al., 2020; Pham et.al., 2019). Therefore, we conducted this study to measure the effect of the Covid-19 pandemic on anxiety levels of medical students in southern Punjab of Pakistan.

\section{Method}

Study was conducted on medical students of southern Punjab, Pakistan via online questionnaire Performa. The Covid-19 fear scale was used to measure the fear and anxiety level in medical students of southern Punjab including Nishtar Medical University, Multan and Quaid-eAzam Medical College, Bahawalpur.

Only the students who filled the Performa willingly and completely were included in the study. The students who were unwilling to participate in the study were excluded. Performa was designed to gather demographic information including age, gender, year of study, residence, and socioeconomic status.

The Fear Covid-19 scale (FCoV-19S) consist of 7 questions evaluated on a 5-point scale; $1=$ strongly disagree, $2=$ disagree, $3=$ neutral, $4=$ agree, $5=$ strongly agree. A total score is calculated as the sum of the 7 items that is ranging from 7 to 35 . The higher the score, the greater is the fear of Covid-19. The acceptable values for the internal consistency and the test retest reliability of the scale were 0.82 and 0.72 . the FCov19s has positive correlation with anxiety and depression level.

\section{Data Analysis}

Data analysis was done by using SPSS-24. Firstly, the mean, standard deviation, and percentages were calculated and reported. The Cronbach's alpha test was applied for reliability analysis and to assess internal consistency. Reliability analysis corresponding to value $>0.70$ was taken satisfactory. Convergent validity, the correlation between the FCoV-19 scale score and its 7 items were derived by Spearman's correlation coefficient.

\section{Results and Discussion}

Pneumonia caused by Covid-19 is a current global health emergency and has been declared as pandemic. Most patients present clinically with symptoms of pneumonia including fever and dyspnea. The World Health Organization (WHO) confirmed Covid-19 cases in more than 150 countries and currently Covid-19 is the major cause of death worldwide. Isolation and quarantine of infected patients are major measure to control the spread of infection. Lockdown to force the public to avoid unnecessary visits at public places is another major step taken as a protective measure. Lockdown has badly affected not only the economy but also the academic career of students due to closure of teaching universities and postponement of examinations (Li, et.al., 2020). The disease has

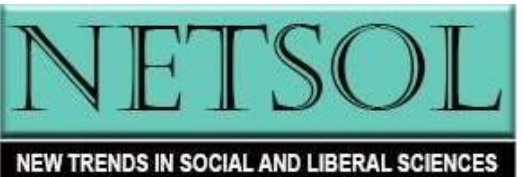


affected the physical health on one side and has impact on mental health of the public by increasing the anxiety level on the other hand. This study that relies on Harper FCov19s has shown that behavior change to control the spread of Covid-19 by adopting preventive behaviors have been effective. A total 577 students participated in this study. Mean age of the participants was 20.4 years with SD of 1.52. Only $8.7 \%$ students were under the age of 18 years, the rest of them were above 18 years (age wise contribution shown in Graph 01).

\section{Graph 01: Showing Age Wise Contribution of Students}

\section{Age Wise Number of Students $(n=577)$}
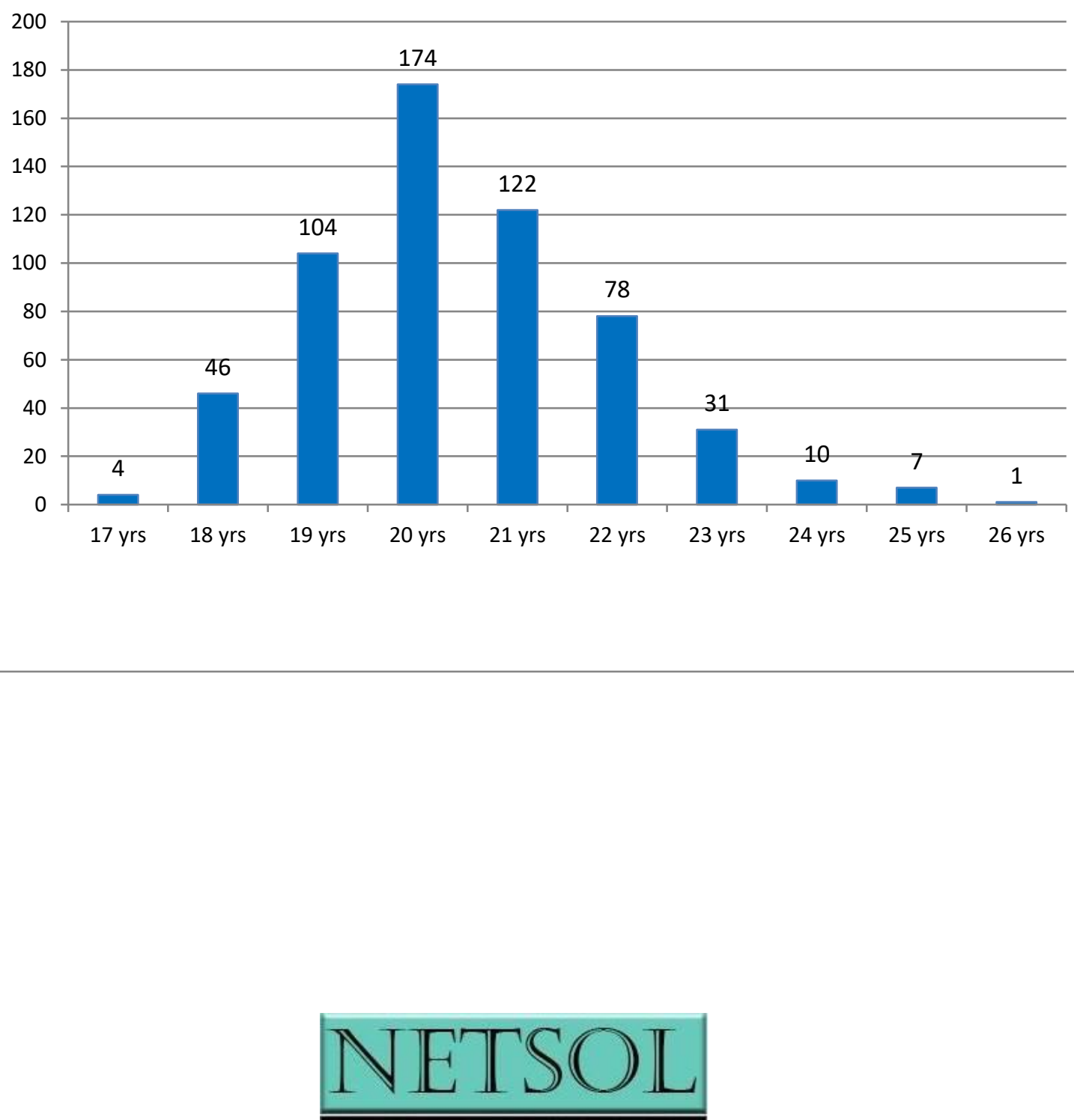
Demographic features are shown in table 01.

Table 01: Showing Demographic Features n=577

\begin{tabular}{|c|c|c|}
\hline $\begin{array}{c}\text { Demographic } \\
\text { Feature }\end{array}$ & Frequency & Percentage \\
\hline \multicolumn{3}{|c|}{ Gender } \\
\hline Female & 351 & 60.8 \\
\hline Male & 226 & 39.2 \\
\hline Total & 577 & 100 \\
\hline \multicolumn{3}{|c|}{ Age } \\
\hline$<18$ & 50 & 8.7 \\
\hline$>18$ & 527 & 91.3 \\
\hline Total & 577 & 100 \\
\hline \multicolumn{3}{|c|}{ Study year } \\
\hline $1^{\text {st }}$ year & 213 & 36.9 \\
\hline $2^{\text {nd }}$ year & 165 & 28.6 \\
\hline 3rd year & 141 & 24.4 \\
\hline 4th year & 34 & 5.9 \\
\hline 5th & 24 & 4.2 \\
\hline Total & 577 & 100 \\
\hline \multicolumn{3}{|c|}{ Day-scholar/Hostelite } \\
\hline Day-scholar & 184 & 31.9 \\
\hline Hostelite & 393 & 68.1 \\
\hline Total & 577 & 100 \\
\hline
\end{tabular}

Female students showed more interest in the study compared to male students as the percentage of female student participants was $60.8 \%$ and that of male student participants was $39.2 \%$. Students residing in hostels responded well compared to day-scholars. This difference in response could be caused by the fact that living far from home and family might be a causative factor for anxiety. The majority of participants were preclinical and junior class students including $1^{\text {st }}, 2^{\text {nd }}$ and $3^{\text {rd }}$ year students constituting $89.9 \%$, showing that clinical students having more patient exposure probably increases the health literacy and confidence level thus showing least interest in anxiety related studies for communicable diseases (class wise contribution shown in Graph 02).

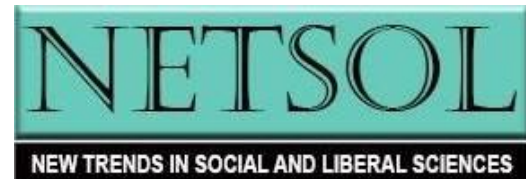




\section{Graph 02: Showing Class Wise Contributions of Medical Students}

$\left(1^{\text {st }} \& 2^{\text {nd }}\right.$ year students are preclinical, $3^{\text {rd }}$ to $5^{\text {th }}$ year students are clinical students)

\section{Year Wise Number of Students $(n=577)$}

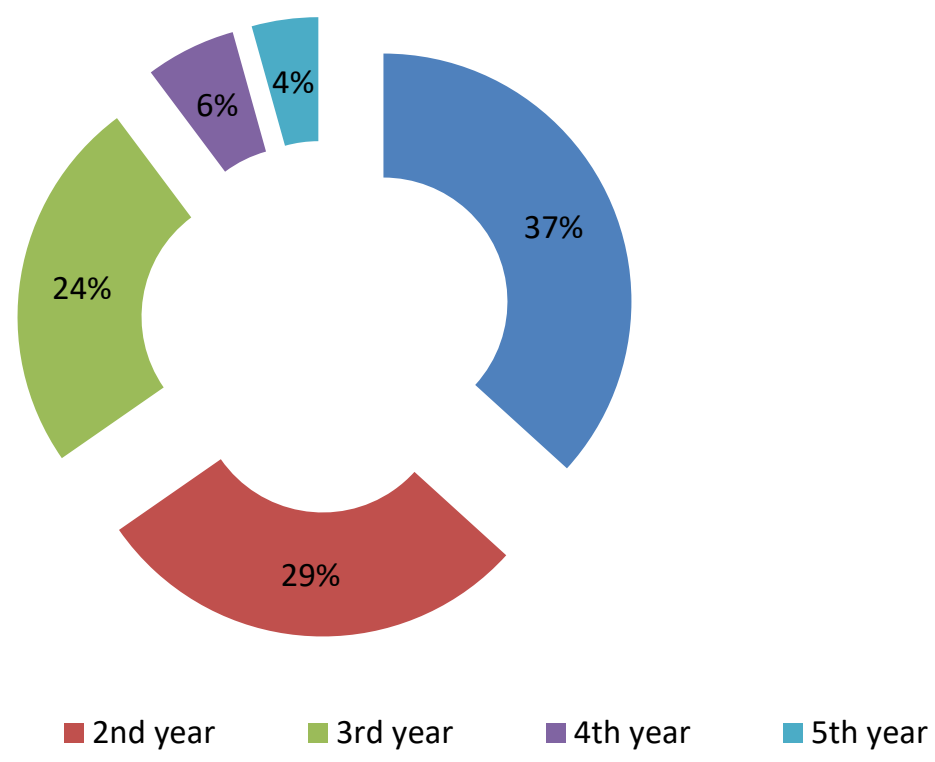

Previous studies have shown a strong correlation of Covid-19 fear with demographic variables including age, gender, socioeconomic status, and health literacy level (Nguyen, et.al., 2020). Our study also shows the factors affecting the anxiety level include gender, level of study, socioeconomic status, living with family or not, and exposure to Covid -19 infected patients. Female students have shown a high anxiety level than male students; that could be due to the fact that women have more stressful life events in normal circumstances (Lancet, 2020). Moreover, female students in general have more prevalence for anxiety and depression than male students (Evans, et.al., 2018; Eaton, et.al., 2012). The anxiety level was higher among junior or preclinical students compared to clinical or senior students. Senior students' better disease related knowledge, skills, and preventive measures might be reducing their Covid fear (Nguyen, et.al., 2020). Students with high socioeconomic status and day-scholars had lower anxiety levels than students living in hostels or students with lower socioeconomic status. It could be explained by the fact that living with family members allows better care for self and dear ones under direct supervision. While feelings of loneliness or isolation increases the depression and anxiety (Domènech-Abella et.al., 2019; Calati,

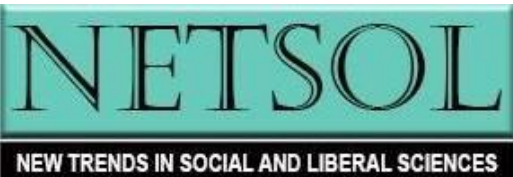


et.al., 2019). Ability to afford medical services and necessary medication is another factor to lower the anxiety level. Previous studies have also shown that children of financially stable parents have lower risk to have psychological problems (Cao, et.al, 2020). Students having exposure to Covid-19 patients have high anxiety levels as compared to those who have not seen such patients around. Exposure to Covid-19 infected patients in surroundings increases the anxiety level especially if patient care had poor outcome. Moreover, management of a patient in isolation away from family members and friends and funeral arrangement after death in absence of family members is also a factor increasing fear of Covid-19.

Our study shows that Fc19s is a reliable and valid tool to assess the pandemic related anxiety level of medical students. Study shows higher values for internal consistency, item-scale convergent validity and floor and ceiling effects. (Descriptive statistics, Component Matrix and Correlation matrix are shown in table $02,03 \& 04$ Respectively). Reliability analysis derived by Cronbach's alpha test was 0.87 .

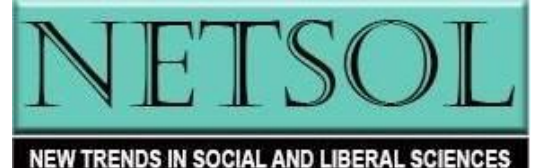




\section{Descriptive Statistics}

\begin{tabular}{|c|c|c|}
\hline \multicolumn{1}{|c|}{$\begin{array}{c}\text { Mean } \\
\text { virus? }\end{array}$} & 3.4495 & Std. Deviation \\
\hline $\begin{array}{l}\text { How uncomfortable does it make } \\
\text { you to think about current Corona } \\
\text { Pandemic? }\end{array}$ & 3.4721 & 1.18309 \\
\hline $\begin{array}{l}\text { How afraid are you of losing your } \\
\text { life because of Corona Pandemic? }\end{array}$ & 3.0976 & 1.47613 \\
\hline $\begin{array}{l}\text { How nervous and anxious do you } \\
\text { get when you hear news about } \\
\text { spreading of Corona virus? }\end{array}$ & 3.6202 & 1.21882 \\
\hline $\begin{array}{l}\text { How afraid are you about } \\
\text { contacting Corona virus? }\end{array}$ & 3.6272 & 1.26451 \\
\hline
\end{tabular}

\begin{tabular}{|c|c|c|}
\hline \multicolumn{3}{|c|}{ Component Matrix ${ }^{a}$} \\
\hline & Raw & Rescaled \\
\hline & Component & Component \\
\hline & 1 & 1 \\
\hline $\begin{array}{c}\text { How afraid are you of Corona } \\
\text { virus? }\end{array}$ & 0.927 & 0.783 \\
\hline $\begin{array}{l}\text { How uncomfortable does it make } \\
\text { you to think about current Corona } \\
\text { Pandemic? }\end{array}$ & 0.864 & 0.740 \\
\hline $\begin{array}{l}\text { How afraid are you of losing your } \\
\text { life because of Corona Pandemic? }\end{array}$ & 1.253 & 0.849 \\
\hline $\begin{array}{l}\text { How nervous and anxious do you } \\
\text { get when you hear news about } \\
\text { spreading of Corona virus? }\end{array}$ & 1.028 & 0.844 \\
\hline $\begin{array}{l}\text { How afraid are you about } \\
\text { contracting Corona virus? }\end{array}$ & 1.073 & 0.848 \\
\hline
\end{tabular}

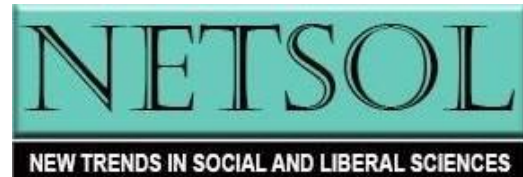




\begin{tabular}{|c|c|c|c|c|c|c|}
\hline \multicolumn{7}{|c|}{ Correlation Matrix ${ }^{a}$} \\
\hline & & $\begin{array}{c}\text { How afraid are } \\
\text { you of Corona } \\
\text { virus? }\end{array}$ & $\begin{array}{c}\text { How } \\
\text { uncomfortable } \\
\text { does it make you } \\
\text { to think about } \\
\text { current Corona } \\
\text { Pandemic? }\end{array}$ & $\begin{array}{l}\text { How afraid are } \\
\text { you of losing } \\
\text { your life } \\
\text { because of } \\
\text { Corona } \\
\text { Pandemic? }\end{array}$ & $\begin{array}{l}\text { How nervous } \\
\text { and anxious } \\
\text { do you get } \\
\text { when you hear } \\
\text { news about } \\
\text { spreading of } \\
\text { Corona virus? }\end{array}$ & $\begin{array}{l}\text { How afraid } \\
\text { are you } \\
\text { about } \\
\text { contacting } \\
\text { Corona } \\
\text { virus? }\end{array}$ \\
\hline \multirow[t]{5}{*}{ Correlation } & $\begin{array}{l}\text { How afraid are } \\
\text { you of Corona } \\
\text { virus? }\end{array}$ & 1.000 & 0.536 & 0.557 & 0.589 & 0.597 \\
\hline & $\begin{array}{c}\text { How } \\
\text { Incomfortable } \\
\text { does it make } \\
\text { you to think } \\
\text { about current } \\
\text { Corona } \\
\text { Pandemic? } \\
\end{array}$ & 0.536 & 1.000 & 0.513 & 0.589 & 0.515 \\
\hline & $\begin{array}{l}\text { How afraid are } \\
\text { you of losing } \\
\text { your life } \\
\text { because of } \\
\text { Corona } \\
\text { pandemic? }\end{array}$ & 0.557 & 0.513 & 1.000 & 0.594 & 0.625 \\
\hline & $\begin{array}{l}\text { How nervous } \\
\text { ınd anxious do } \\
\text { you get when } \\
\text { you hear news } \\
\text { about } \\
\text { spreading of } \\
\text { Corona virus? }\end{array}$ & 0.589 & 0.589 & 0.594 & 1.000 & 0.701 \\
\hline & $\begin{array}{l}\text { How afraid are } \\
\text { you about } \\
\text { contacting } \\
\text { Corona virus? }\end{array}$ & 0.597 & 0.515 & 0.625 & 0.701 & 1.000 \\
\hline
\end{tabular}

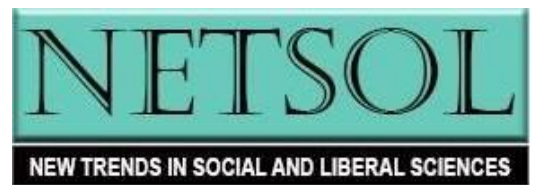




\section{Conclusion}

The Covid-19 pandemic has not only resulted in worldwide economic downfall and burden on health care systems but also has strong psychological impact causing fear of Corona virus among medical students. Our study shows health literacy has a positive impact on Corona fear, so enhancing the knowledge about Covid-19 and protective measures against its spread has key role in control of its spread on one hand and to lower the anxiety level on other hand. Therefore, there is need for public health interventions and strategic plans for education and training programs for medical students to reduce their anxiety level.

\section{Disclosure Statement}

All authors guarantee that there is no conflict of interest either directly or indirectly.

\section{Funding Source}

There is no funding body or sponsor for publication of this article.

\section{Contribution of Authors}

All the authors contributed significantly to manuscript writing. M. Ahmad Mukhtar is main author for manuscript writing (40\%). Dr. Mukhtar Hussain (20\%), M. Omer Mukhtar (20\%) and M. Sajid (20\%) contributed to collection of record and maintaining it and in critical review of manuscript.

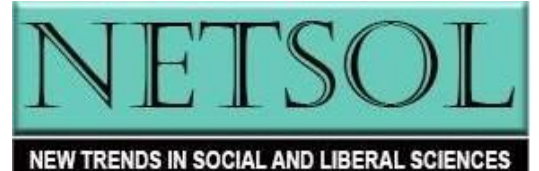




\section{References}

Ahorsu, DK. Lin C-Y, Imani V, Saffari M, Griffiths MD, Pakpour AH. "The Fear of COVID-19 Scale: Development and Initial Validation", International Journal of Mental Health and Addiction, 2020: pp.1-9.

Calati, R. Ferrari C, Brittner M, Oasi O, Olié E, Carvalho AF, et al. "Suicidal Thoughts and Behaviors and Social Isolation: A Narrative Review of the Literature" Journal of Affective Disorders, 2019; 245: pp.653-67.

Cao W. Fang Z, Hou G, Han M, Xu X, Dong J, et al. The Psychological Impact of the COVID-19 Epidemic on College Students in China", Psychiatry Research. March 2020:227. pp.1-5.

Chong M-Y, Wang W-C, Hsieh W-C, Lee C-Y, Chiu N-M, Yeh W-C, et al. "Psychological Impact of Severe Acute Respiratory Syndrome on Health Workers in a Tertiary Hospital." The British Journal of Psychiatry, 2004:185 (2): pp.127-33.

Domènech-Abella J, Mundó J, Haro JM, Rubio-Valera M. "Anxiety, Depression, Loneliness and Social Network in the Elderly: Longitudinal Associations from the Irish Longitudinal Study on Ageing (TILDA)" Journal of Affective Disorders. 2019; 246: pp.82-8.

Eaton, NR, Keyes KM, Krueger RF, Balsis S, Skodol AE, Markon KE, et al. "An Invariant Dimensional Liability Model of Gender Differences in Mental Disorder Prevalence: Evidence from a National Sample", Journal of Abnormal Psychology. 2012: 121(1): 282.

Elnour AA, Don J, Yousif I, Gnana K, Abdi S, Alhajri N, et al. "The Early Mortality Rate of People Infected with Coronavirus (COVID-2019) in Wuhan, China: Review of three retrospective studies." Journal of Pharmacy and Bioallied Sciences. 2020: 12(3):223.

Evans TM, Bira L, Gastelum JB, Weiss LT, Vanderford NL. Evidence for a mental health crisis in graduate education. Nature biotechnology. 2018;36(3):282.

French, S.L, Floyd M, Wilkins S, Osato S. "The Fear of Alzheimer's Disease Scale: A New Measure Designed to Assess Anticipatory Dementia in Older Adults", International Journal of Geriatric Psychiatry, 2012:27(5): pp.521-8.

Harper CA, Satchell LP, Fido D, Latzman RD. "Functional Fear Predicts Public Health Compliance in the COVID-19 Pandemic", International Journal of Mental Health and Addiction. 2020: April 27: pp.1-14.

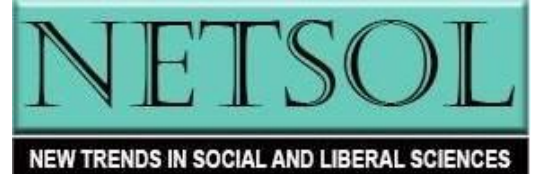

44 
Huremović, D. Psychiatry of Pandemics: a Mental Health Response to Infection Outbreak, Cham, Switzerland Springer, 2019.

Kaper MS, Reijneveld SA, van Es FD, de Zeeuw J, Almansa J, Koot JA, et al. "Effectiveness of a Comprehensive Health Literacy Consultation Skills Training for Undergraduate Medical Students: A Randomized Controlled Trial." International Journal of Environmental Research and Public Health. 2020;17(1):81.

Lancet T. "The Gendered Dimensions of COVID-19" Lancet, 2020: 395 (10231):1168.

Li HY, Cao H, Leung DY, Mak YW. "The Psychological Impacts of a COVID-19 Outbreak on College Students in China: A Longitudinal Study" International Journal of Environmental Research and Public Health. 2020: 17(11): 3933.

Mayer Y, Etgar S, Shiffman N, Lurie I. The Fear of COVID-19 Familial Infection Scale: Initial Psychometric Examination. Preprint: May, 2020: Retrieved on May 8, 2021 from https://psyarxiv.com/edwta/

Moshki M, Shahgheibi S, Taymoori P, Moradi A, Roshani D, Holt CL. "Psychometric Properties of the Mammography self-efficacy and Fear of Breast Cancer Scales in Iranian Women", BMC Public Health, 2017: 17 (1): pp.1-9.

Nguyen HT, Do BN, Pham KM, Kim GB, Dam HT, Nguyen TT, et al. "Fear of COVID-19 ScaleAssociations of Its Scores with Health Literacy and Health-Related Behaviors among Medical Students", International Journal of Environmental Research and Public Health, 2020: 17 (11):4164.

Pakpour AH, Griffiths MD. "The Fear of COVID-19 and its Role in Preventive Behaviors", Journal of Concurrent Disorders, 2020:2(1): pp.58-63.

Pham T, Bui L, Nguyen A, Nguyen B, Tran P, Vu P, et al. The Prevalence of Depression and Associated Risk Factors Among Medical Students: An Untold Story in Vietnam", PloS one, 2019: 14 (8): e0221432.

Sher L. "Resilience as a Focus of Suicide Research and Prevention", Acta Psychiatrica Scandinavica. 2019:140 (2): pp.169-80.

Sher L. The Impact of the COVID-19 Pandemic on Suicide Rates", QJM: An International Journal of Medicine, 2020;113(10): pp.707-12.

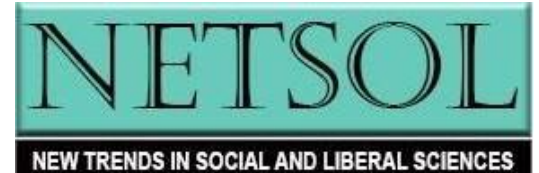


Tannenbaum MB, Hepler J, Zimmerman RS, Saul L, Jacobs S, Wilson K, et al. "Appealing to Fear: A Meta-analysis of Fear Appeal Effectiveness and Theories", Psychological Bulletin. 2015: 141 (6): 1178.

Wang, Dawei, Bo Hu, Chang Hu, Fangfang Zhu, Xing Liu, Jing Zhang, et al. "Clinical Characteristics of 138 Hospitalized Patients with 2019 Novel Coronavirus-Infected Pneumonia in Wuhan, China" JAMA. 2020;323(11):1061-1069. doi:10.1001/jama.2020.1585

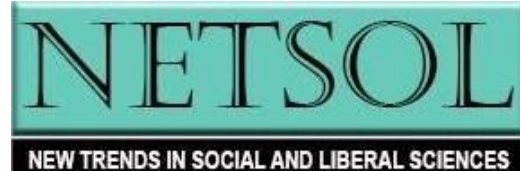

